\title{
Malignant External Ear Neoplasm
}

National Cancer Institute

\section{Source}

National Cancer Institute. Malignant External Ear Neoplasm. NCI Thesaurus. Code C4653.

A malignant neoplasm that affects the external ear. Representative examples include squamous cell carcinoma, basal cell carcinoma, and ceruminous adenocarcinoma. 